forms appear and all the ratios were consistent with the $1: 1$ expected from a back-cross. The results are thus fully in agreement with the hypothesis that carbonaria and insularia are controlled by allelomorphs at the same locus and that carbonaria is dominant to insularia and both are dominant to typical.

There is thus good evidence that at least some of the genes controlling insularia, both from Oxford and from Cheshire, are allelomorphic with those determining carbonaria. It is, therefore, clearly desirable to investigate insularia, both darker and lighter than those studied in the present investigation, to ascertain how many loci are concerned. If several are found, this will be of considerable importance in investigations into the evolution of industrial melanism in $B$. betularia.

Department of Medicine,

Department of Genetics,

The University of Liverpool.

${ }^{1}$ Kettlewell, H. B. D., Heredity, 12, 51 (1958).

${ }^{2}$ Kettlewell, H. B. D., Heredity, 9, 323 (1955).

s' (larke, C. A., and Sheppard P. M., Nature, 198, 1279 (1963).

\section{Graft-induced Sex Changes in Cucumis melo L.}

IN normally monoecious melons (bearing both male and female flowers) the occurrence of andromonoecious (mostly staminate with fewer perfect flowers), hermaphroditic (all perfect flowers), and even gynomonoecious (mostly pistillate with fewer staminate or perfect flowers) plants have been reported ${ }^{1}$. The latter type would be of considerable value in genetic work. Previous attempts to establish genotypically pure female lines have failed owing to the difficulty of obtaining pollen for inbreeding. In the recorded work here, it is reported that grafting of a gynomonœcious scion to selected andromonocious understocks will temporarily induce formation of male flowers on the gynomonœeious scion.

Regulation of sex expression in musk-melon plants by various environmental treatments ${ }^{1}$ and in plants related to the melon by hormonal treatments ${ }^{2-5}$ has been reported. The plants used in the present studies did not, however, respond to such treatments. A previous report of a graft-induced change in sex expression of hops ${ }^{6}$, and studies from this laboratory ${ }^{7}$ on the effects of grafting on pollen-style compatibility in Enothera, together with the recent report of Pringle on a specific male sex inducing substance ${ }^{8}$, suggested grafting as a possible means of inducing sex changes in melon plants. The graft-induced formation of male flowers on a gynomonocious plant here reported could be explained by the diffusion of either a macromolecular substance or a low molecular weight hormone across the graft union.

Seedlings of Spartan Rock, an andromonœcious variety of Cucumis melo L., of Cucurbita pepo L., or rooted clona cuttings of the gynomonœeious musk-melon were used as understocks. A cleft graft was made at the twentieth node of the stock by inserting a $5-7 \mathrm{~cm}$ long seion from the gynomonocious plant in a manner such that the cut end of the scion could be dipped into a vial containing water. The graft union was normally established in 2-3 weeks, after which time the vial and the cut end of the scion could be removed.

A gynomonœcious musk-melon plant was found by Dr. C. E. Peterson among the $F_{2}$ progeny from a cross between moncecious $\times$ hermaphroditic plants and was multiplied by vegetative propagation. Gynomonœeious seedlings for grafting experiments were selected from the inbred population of each successive generation. The scions were detached from the mother plant and grafted to the andromonœeious seedlings of musk-melon or of pumpkin. The results of such graftings are presented in Table 1. Usually three replicate grafts of each treatment were made. One can conclude from Table 1 that grafting of a gynomonœcious musk-melon scion to andromonœcious seedlings of the same species or of pumpkin greatly increased the induction of staminate flowers. The induction was generally higher in grafts on seedlings of the same species and decreased as the homozygosity of the scions increased, levelling off in the $F_{4}$ generation. The absence of staminate flowers in the $F_{4}$ and $F_{5}$ of control plants may be explained by the small number of plants observed. The reappearance in the $F_{6}$ controls is roughly onetwentieth of the calculated value to be expected in an inbred population, assuming bifactorial inheritance ${ }^{1}$.

Table 1. EFFect of Grafting on the IndUCtion of Staminate Flowers IN SHRT G

Generations of inbreeding for the gynomoncecious

Viagrafted control Treatment

(1) No. of clonal plaut

(2) No. of nodes observed

(3) Per cent staminate flowers formei

2. Control-grafted to gynomonoerious musk-

melon

(1) No. of clonal plants

(3) Per cent staminate flowers formed

3. Grafted to andromonocious musk-melon

(1) No. of clonal plants

(3) Per cent staminate flowers formed

$\begin{array}{lllll}F_{2} & F_{3} & F_{4} & F_{5} & F_{6}\end{array}$

$\begin{array}{rrrrr}3 & 1 & 1 & 1 & 5 \\ 41 & 43 & 54 & 76 & 17 \%\end{array}$

$\begin{array}{rrrrr}0.7 & 0 \cdot 5 & 0 & 0 & 0.2\end{array}$

Grafted to andromonocious pumpkin

seedlings

(1) No. of clonal plants

2) No. of nodes observed

Per cent staminate flowers formed

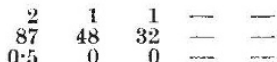

In addition to the induction of staminate flowers on a previously pistillate scion by means of grafting, the distribution pattern of the staminate flowers also changes. This is illustrated by data from four representative plants (Table 2). In general, the induction of staminate flowers occurs at an earlier node as compared to the spontaneous occurrence of male flowers in control plants.

Table 2. DISTRIBUTION OF STAMINATE FLOWERS FORMED ON REPRESENTATIVE GYNOMONOECIOUS MUSK-MELON SCIONS AS A RESPONSE TO UNDERSTOCK

$\begin{array}{lcccc}\text { Treatments } & \begin{array}{c}\text { Sex of flowers formed on main } \\ \text { axis after } \\ \text { Pistillate }\end{array} & \begin{array}{c}\text { grafting } \\ \text { Staminate }\end{array} & \begin{array}{c}\text { (Node No.) } \\ \text { Pistlllate }\end{array} \\ \text { (1) Ungrafted control } & 1-39 & 40 & 41-43 \\ \text { (2) Control-grafted to gynomonœcious } & 1-37 & 38 & 39-48 \\ \text { (3) Gusk-melon } & \begin{array}{c}\text { Grafted to andromonocious musk- } \\ \text { melon seedling }\end{array} & 1-17 & 18-33 & 34-65 \\ \text { (4) Grafted to andromonocious } & 1-10 & 11-12 & 13-44\end{array}$

It is also of interest that the graft-induction of male flowers is a temporary effect, in this respect being similar to the graft effects reported for CEnothera? ${ }^{7}$. The induction effect usually begins and ends with the formation of nodes with hermaphroditic flowers or nodes bearing pistillate and staminate flowers simultaneously. Cases where the succession of staminate nodes is interrupted by mixed or pistillate ones also occur, especially at both ends of an induced portion of the axis.

This work was supported in part by the Michigan Agricultural Experiment Station, by the U.S. National Science Foundation ( $G$ 22069) and the U.S. Public Health Service (AM 05916). We thank Dr. C. E. Peterson for providing us with the original $F_{2}$ plants and Dr. R. S. Bandurski for his advice.

Department of Horticulture,

\section{JoSEPH M. MOCKAITIS}

Aleksander KiviluaAn

Department of Botany and Plant Pathology, Michigan State University,

East Lansing, Michigan.

1 Poole, C. F., and Grimball, P. C., J. Hered., 30, 21 (1939).

Wittwer, S. H., and Bukovac, M. J., Econ. Bot., 12, 213 (1958).

${ }^{3}$ Peterson, C. E., and Anhder, L. D., Science, 131, 1673 (1960).

4 Galun, E., Genetica, 32, 134 (1961).

Galun, E., Jung, Y., and Lang, A., Nature, 194, 596 (1962).

' Limberk, J., Cs, Biologie (Praha), 3, 252 (1954).

' Kivilaan, A., and Chang, C. W., Nature, 197, 1130 (1963).

Pringle, R. B., Seience, 133, 284 (1961). 